\title{
Реалізація дериваційної спроможності відсубстантивних дієслів зі значенням «діяти інструментом, названим твірною основою»
}

\author{
ОКСАНА КУШЛИК \\ Дрогобицький державний педагогічний університет імені Івана Франка, \\ вул. I. Франка 24, UA-82100 Дрогобич \\ E-mail: oksana_kushlik@ukr.net
}

(Received: 7 June 2015; accepted: 19 August 2015)

\begin{abstract}
This paper analyzes the derivation capability of verbs motivated by substantives with the word-formation meaning 'to work with a tool, named by a word-forming noun' with suffix - -ува-/-юва- in the Ukrainian language. The author claims that the typical word-forming paradigm is formed of three word-formation zones: substantive, adjective, and verbal. Within each zone, a continuum of word-forming derivatives is distinguished, a set of word-forming devices for their realizations is determined, and the abilities of some of them to express additional lexical meanings are traced.
\end{abstract}

Keywords: Ukrainian, word formation, substantivised verbs, derivative stem, perfective

Дослідження словотвірного потенціалу дієслів як одного з найскладніших морфологічних класів слів 3 розгалуженою системою граматичних категорій та їх матеріальних виразників - граматичних форм, здійснюване у світлі основоцентричного напряму дериватології, становить важливий етап системного обстеження усієї мотивувальної бази сучасної української мови. Опертя на твірну основу, iï функціональне навантаження у словотвірних процесах дає змогу передбачити формування дериватів з певним словотвірним значенням, визначити інвентар словотворчих засобів для його експлікації, з'ясувати вплив мовних та позамовних чинників на реалізацію закладених системою мови дериваційних можливостей, що є необхідним для установлення відповідної типології словотвору.

Показником дериваційного потенціалу аналізованого слова вважають словотвірну парадигму - комплексну системоутворювальну одиницю, що являє собою сукупність дериватів одного ступеня творення, об'єднаних тотожністю твірної основи (ЗЕмСКАЯ 1978: 71, ГРЕщук 2007: 10) і протиставлених словотворчими формантами (ВАлюх 2005: 29).

У зарубіжному мовознавстві відомі спроби створення типології словотвірних парадигм дієслів. Так, словацька дослідниця К. Бузашшіова однією 3 перших у слов'янському мовознавстві використала поняття «словотвірна парадигма» для класифікації й опису девербативів словацької мови (пор. BuZÁsSYOVÁ 1974). Словотвірні потенції дієслів у російській мові досліджували О. Земська, Т. Морозова, С. Тихонов, Т. Чиканцева, Т. Яруліна (ЗЕмскАя 1982, 
МоРОзовА 1984, Тихонов 1982, ЧикАНЦЕВА 1984, ЯрулЛИНА 1980); у польській мові - Р. Гжегорчикова, Г. Ядацька (Grzegorczyкowa 1969, JADACKA 2001, ЈАDACKA 2004); у болгарській - С. Калдиєва-Захарієва, Є. Георгієва, В. Нечаєва (КАЛДИЕВА-ЗАХАРИЕВА 1977, ГЕОРГИЕВА 1963, НЕЧАЕВА 1984); в англійській Т. Бєляєва (БЕЛЯЕВА 1974).

Низку наукових праць присвячено проблемам зіставно-типологічного вивчення дієслівного словотворення. Зокрема, Р. Маначурян порівняв словотвірну поведінку дієслівних основ російської та вірменської мов (МАНАчурян 1981), А. Лукашанець - російської та білоруської (ЛукАшАнЕц 1981), Є. Бразаускене - російської та литовської (БРАЗАУсКЕНЕ 1991), Л. Сегін - української та польської (СЕГін 2003), І. Ступак - української та німецької (СтуПАк 2011), Т. Возний - української, російської та білоруської (Возний 1981), Н. Ярошенко - української, російської та польської (ЯРОшенко 2004), А. Пузік - української, англійської та німецької (Пузік 2000), Т. Ацаркіна - польської, чеської та російської (АцАРКИНА 1997).

Україністика теж має певні надбання у цій сфері. Установлено типологію словотвірних парадигм деяких лексико-семантичних груп здебільшого первинних дієслів (ДжочкА 2003, ПослАвсьКА 2006). Розпочато системне обстеження дериваційної спроможності похідних дієслів, зокрема відприкметникового (Кушлик 2012b, 2012c, 2012d, KUSHLYк 2013) та відзвуконаслідувального походження (Кушлик 2011, 2012a). Проте цей цикл студій був би неповним без дослідження словотвірних можливостей відіменникових (відсубстантивних) дієслівних основ. 3 огляду на, по-перше, центральність дієслівного та іменникового класів слів, а по-друге, їхню полярність і водночас функціональну єдність (ВАлюх 2005: 136) аналіз цього матеріалу є актуальним насамперед для віддієслівного словотвору та важливим для розуміння й передбачуваності словотвірної поведінки всіх «учасників» дериваційного процесу.

Увагу у пропонованій розвідці зосереджено на відсубстантивних дієсловах зі значенням «діяти інструментом, названим твірною основою». Лексикосемантична група іменників на позначення знарядь (інструментів) та засобів дії, що слугують мотиваторами таких вербативів, доволі неоднорідна за своїм складом. Передусім вона охоплює різні за походженням одиниці: одну частину назв становлять непохідні, або первинні, іменники (пор.: багор, батіг, борона, брус, веретено, весло, граблі, жолоб, коса, лопата, плуг, решето, cana, цзвях тощо), іншу - похідні, або вторинні, утворені від дієслівних основ здебільшого внаслідок суфіксації (пор.: косарка, молотарка, жатка, рубанок, вимірювач, точило, кресало, розсійник та ін.) (ВАлюх 2005: 186-187). Неоднаковим $є$ також і їхнє функціональне навантаження. Одні з них номінують предмети, які використовують під час виконання фізичної дії у повсякденному вжитку. Інші належать до сфери обмеженого використання і залежно від ступеня узагальнення, рівня офіційності назви та середовища поширення іiі формують групи термінів чи - рідше - професіоналізмів. Серед термінів вирізняють чужомовні й автохтонні. Уживання кожного з них зумовлює співвідношення інтернаціонального і національного у межах усієї термінної 
системи. Перший складник єднає ії з міжнародними стандартами, інший, виявляючи самобутність, зберігає народний характер (СЕлІгЕй 2007: 20). Усе це певною мірою визначає активність іменників на позначення знарядь чи засобів дії щодо продукування дієслів.

Вершинні дієслова постають унаслідок суфіксації. До основних словотворчих засобів належать суфікси: 1) -ува-/-юва-, пор.: боронувати, вальцюювати, зенкерувати, зондувати, кайлувати, кардувати, млинкувати, помпувати, пресувати, сапувати, фрезерувати, чизелювати тощо; 2) -и-, пор.: батожити, бомбити, вудити, гарпунити, косити, ралити тощо; 3) -а-, пор.: вінчати, латати, пиляти, путати, сапати, сідлати, стріляти тощо.

За мету ставимо собі установити дериваційний потенціал відсубстантивних дієслів, утворених за допомогою суфікса -ува-/-юва-. Ця група вербативів в українській мові відзначається особливою продуктивністю, що спричинено: по-перше, популярністю самого словотворчого засобу, за допомогою якого найчастіше утворюються дієслова (ГородЕНськА 1981: 29, Юрчук 1979: 173, УГ-1986: 223), до того ж як від основ автохтонних слів, пор.: грабкувати, кайлувати, кардувати, клеймувати, коткувати, млинкувати, решетувати, сапувати тощо, напр.: «Гукович прийшов на тік, заглянув у здорову клуню, де млинкували пашню» (НЕчуй-ЛЕвицький 1967: 307), так і чужомовних, пор.: букерувати, буксирувати, вальцุювати, гільйотинувати, грейдерувати, дискувати, каландрувати, помпувати, катапультувати, кернувати, компостувати, нівелювати, пресувати, скреперувати, трісрувати, флейцюювати, чизелювати та ін., напр.: «- Тут все у ваших руках, генерале. А для таких, як ви, професіоналів немає складності грамотно катапультувати хлопців» (ТЕСлЕнко 1989: 288); по-друге, достатньо вигідними умовами поєднання твірної основи і словотворчого засобу (твірна іменникова основа здебільшого повністю, без будь-яких змін входить до складу дієслівної - ГороденсьКА 1981: 30); по-третє, широкою мотивувальною базою - іменниками на позначення знарядь (інструментів) і засобів, кількість яких з огляду на безперервний розвиток науки і техніки постійно зростає.

Типову словотвірну парадигму вербативів цієї семантики формують переважно три словотвірні зони - субстантивна, ад'єктивна і вербальна. Специфіку субстантивної зони становить наявність дериватів 3 транспозиційним і мутаційним значенням. Виразником транспозиційного значення «опредметнена дія» є суфікс -нн-. Виявляючи особливу дієслівність, він максимально зближує семантику і граматичні властивості вербатива та девербатива (пор. ОЛЕКСЕнко 2005: 209). Здатність переводити дієслівну основу до іменникової виявляють усі вершинні дієслова, пор.: боронування, букерування, буксирування, вальцювання, гальмування, гільйотинування, дискування, зенкерування, зондування, кайлування, каландрування, кардування, катапультування, кернування, клеймування, компостування, коткування, млинкування, нівелювання, помпування, пресування, решетування, сапування, скреперування, таврування, трісрування, фільтрування, флейцювання, фрезерування, фрезування, цьяяхування, циклювання, чизелювання, шабрування, шлюзування, шнурування, 
шоломпування, шпунтування, штампування, шустування тощо, напр.: «Та й тут [бурлака] непогано прислужується, не відаючи того, що не помине батогів, таврування і довічної каторги» (СиРотюк 1984: 229); «Фрезерування циліндричними фрезами є одним з розповсюджених видів оброблення різанням деталей машин» (ЧумАК 2000: 271). Іменники на позначення знарядь (інструментів) і засобів здебільшого стилістично марковані. Ця маркованість простежується у мотивованих ними вербативах і відповідно девербативах, серед них і іменниках на -нн-[-я], які є основним засобом для називання дій, виробничих процесів у різних галузях промисловості чи сферах діяльності (пор. Пıлецький 2004: 430). До того ж одні терміни можуть бути вузькоспеціальними, тобто позначати поняття лише в межах однієї сфери, зокрема аграрної, пор.: боронування, букерування, дискування, коткування, сапування, трієрування, фрезування, чизелювання, шлейфування (Познанський 2014: 222), напр.: «Технологічні процеси при механічному обробітку грунту здійснюють за допомогою кількох прийомів обробітку грунту, з яких основними є оранка, лущення, культивація, боронування, шлейфування, коткування і фрезування. Фрезування застосовують під час освоєння осушених боліт, а також на дуже задернілих грунтах» (Войтюк 2008: 107); металообробної, пор.: вальцџювання, клеймування, пресування, фрезерування, штампування тощо (СТАХовсьКА 2002), напр.: «Вальцювання є найпоширенішим видом оброблення тиском металів, сплавів та інших конструкційних матеріалів» (ЗБожнА 2002: 309); гірничодобувної, пор.: зондування, кайлування, нівелювання, скреперування (ВАСилЕнко-ШЕлудько 2008), напр.: «Сукупність геодезичних вимірювань, які виконують з метою визначення перевищень між точками фізичної поверхні Землі, будівельних конструкцій або їх висот відносно прийнятої початкової поверхні називають нівелюванням» (ШАульський 2012: 25) тощо. Інші, називаючи споріднені виконувані дії, є міжгалузевими, тобто належать до кількох терміносистем.

Віднесення того чи того терміна до міжгалузевого зумовлює також полісемність його. Більшість іменників, які мотивують аналізовану групу дієслів, моносемні. Така стрункість і прозорість їхньої структури у словотворенні сучасної української мови сприяє продукуванню девербативів на -нн-[-я] (Родніна 1980: 76). Проте іноді мотивувати вершинні дієслова можуть і полісемні іменники, які залежно від сфери їхнього використання позначають різні предмети, пор.: зонд - 1. 'медичний інструмент у вигляді металевої палички або гумової трубки, що вводиться у порожнини і канали тіла 3 діагностичною, лікувальною метою чи як розширювач'; 2. 'повітряна куля із самозаписувальними приладами, яку запускають для спостереження за метеорологічними явищами'; 3. 'металевий бурав для дослідження глибоких шарів грунту; щуп'; 4. 'металевий електрод для визначення електричного потенціалу в чому-небудь'; 5. 'засіб вимірювання або контролю, спеціально пристосований для проведення вимірювань або зчитування інформації в заданій точці' (ВТС 2009: 476). Похідне дієслово зондувати і відповідно його транспозит зондування зберігають увесь семантичний обсяг мотивувального слова, що 
відображено у тій чи тій терміносистемі, пор.: «Запропонований спосіб стимуляції жовчного міхура дозволяє проводити дуоденальне зондування на сучасному рівні з урахуванням фаз його діяльності» (КлАвдієвА 2000: 2); «Комплексне зондування атмосфери здійснюється в шарі атмосфери до 30 км від поверхні землі та за часом відповідає 1,5 год» (Бєляков 2011: 144); «Метод визначення показників властивостей грунтів за результатами зондування має недолік» (ЖдАновА 2006: 3); «У розділі другому описано метод зондування плазми пучком важких іонів і його можливості» (ДревАль 2005: 3); «На основі порівняння даних супутникового зондування, аерологічних вимірювань та даних чисельного моделювання виконано перевірку якості відновлення температури і вологості» (БоБРишев 2014: 384).

Реалізацію семантичної позиції «опредметнена дія» можуть здійснювати

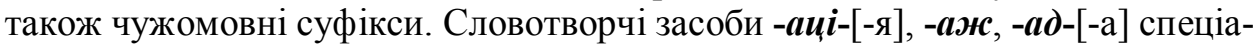
лізуються на творенні девербативів від основ слів іншомовного походження, пор.: нівелячія, тампонація, фільтрація; тампонаж, тампонада, напр.: «Акваріумна фільтраиія - це дуже складний багатоступінчастий процес, у якому комплексно використовуються як механізми, аналогічні до природних, так i спеціально розроблені інші технології»; «Суть запропонованого способу відновлення заобробного грунту тампонажем полягає у тому, що в грунті вибурюють свердловину, установлюють обсадну трубу та ін'єктор, через який, зворотно-поступово переміщуючи по висоті масиву, нагнітають тампонажний розчин». ${ }^{2}$ Сформовані за допомогою цих формантів віддієслівні іменники постають дублетами тих, що утворилися за допомогою суфікса -нн-, пор.: нівелячія - нівелювання, фільтрачія - фільтрування, тампоначія - тампонаж-тампонада - тампонування тощо.

Засобом вираження іншої семантичної позиції - «суб'єкт дії» - є суфікс -льник (варіант суфікса -ник). Він продукує девербативи, що вживаються для називання осіб - виконавців конкретної дії у певному виробничому циклі (БЕЗПОЯСКО-ГОРОДЕНСЬКА 1987: 60, ОЛЕКСЕНКО 2005: 21, СТАХОВСЬКА 2002: 5). Приєднання цього форманта до твірної основи (здебільшого недоконаного виду) зумовлює появу слова з новим лексичним значенням, що характерно для мутаційних семантичних змін. Їх системно зазнає більшість аналізованих вершинних дієслів, пор.: боронувальник, вальиювальник, карбувальник, клеймувальник, нівелювальник, пресувальник, сапувальник, таврувальник, фільтрувальник, фрезерувальник, цииклювальник, шабрувальник, шприцювальник, штампувальник тощо, напр.: «Оксанин прес стояв далеченько від преса Кардибаєва, але пресувальники бачили одне одного» (ТкАч 1988: 442); «- Кожен учитель вічний. Йшов на пенсію наш шліфувальник. П'ятнадцять років працював на заводі» (Бччуя 1982: 15).

Зростанню продуктивності суфікса -льник у вираженні словотвірного значення «суб' єкт дії» сприяють соціальна необхідність породжуваних ним

\footnotetext{
${ }^{1} \mathrm{http} / / /$ aquaprofi.com.ua/eheim-blog/58-osnova-biofiltracia

${ }^{2} \mathrm{http}$ //uapatents.com/2-54747-sposib-vidnovlennya-zaobrobnogo-gruntu-tamponazhem.html
} 
дериватів, термінотворчий потенціал, відсутність ознак інтенсивності та суб'єктивної оцінки, високий ступінь дієслівності похідних лексем (МАмРАК 1982: 48). Актуалізація кожного з цих факторів слугує поштовхом для постійного творення агентивів у межах однієї чи кількох терміносистем. Тому цілком передбачуваною є наявність у словотвірних парадигмах вершинних дієслів похідних одиниць на позначення суб'єкта дії, не зафіксованих лексикографічними джерелами, проте часто використовуваних у відповідних сферах, пор.: бомбувальник, грейдерувальник, дискувальник, кайлувальник, мінувальник, илюзувальник тощо, напр.: «У 60-х роках канадський фермер Фред Келлоу зі своїми двома синами розчищали чагарник і розорювали грунт під поля у неозорій і суворій Північній Альберті. Використовувані ними дискувальники ніяк не могли упоратися з роботою» (І. Петренко). ${ }^{3}$

Рідше так звані агентивні іменники можуть бути оформлені за допомогою іншого варіанта суфікса -ник--івник, пор.: вальцівник, кайлівник, напр.: «Степан крутив у руках його заяву про прийом на роботу. - Вальцівник? спитав він. - Так» (ЗАГРЕБЕЛЬНИй 1961: 320).

Трапляється, що виразниками однієї семантики у межах тієї ж словотвірної парадигми водночас може бути два засоби - суфікси -івник та -льник, пор.: вальцівник і вальц̧ювальник (ВТС 2009: 110), напр.: «Раніше разом у нічну зміну їдив мужик з під’їзд, вальцівник Проценко, і матері було безпечніше...» (ВольвАч 2010: 11) і «...люблю дивитись на нашого брата металурга, на якого-небудь вальцювальника, що стоїть на своєму робочому місці.., а біля ніг у нього мчать розпечені червоні гадюки...» (ГончАр 2001: 252). Паралельне існування дериватів, утворених двома згаданими формантами, поперше, засвідчує дублетність форм для вираження словотвірного значення, а по-друге, дає підстави для констатації глибини семантичної позиції словотвірної парадигми.

Дещо інші семантичні відношення виникають між словами кайлівник і кайлувальник. Девербатив кайлівник, утворений за допомогою суфікса -івник, передає два лексико-семантичні варіанти: 1. 'майстер, що виготовляє кайла'; 2. 'робітник, який кайлом відбиває гірську породу, розбиває каміння, кам'яне вугілля’ (ВТС 2009: 514). У «Словнику гірничої термінології» 1931 року друге зі вказаних значень було реалізоване за допомогою деривата кайлувальник (ВАСилЕнко-ШЕлудько 2008: 129). Проте внаслідок розгорнутої кампанії боротьби 3 «українським буржуазним націоналізмом» та «шкідництвом на мовному фронті» і відповідних офіційних настанов - «не вносити штучної відмежованості української мови від російської», «не подавати ніяких штучних, вигаданих, націоналістичного типу слів» (КуБАйчук 2004: 147-158) - компонентний склад і якість цього та інших термінологічних словників зазнали серйозних змін. Це зумовило заміну іменника кайлувальник словом кайлівник як українським відповідником російського кайловщчик (КАлинович 1948: 181). Цей же варіант значиться у наступних редакціях російсько-українського слов-

${ }^{3}$ www.agro-business.com.ua/mekhanizatsiia-apk/1548-dyskovi-gruntoobrobni-znariaddia.html 
ника (ГоловАщук 1969: 532, БІлодід 1987: 642). Згодом семантика іменника кайлівник конкретизувалася двома лексико-семантичними варіантами, поданими вище.

Дериват кайлувальник у сучасних лексикографічних джерелах не значиться. Проте він поширений у мовленні - для називання інструмента (механізму) у певному виробничому процесі. Очевидно, що девербатив кайлувальник із семантикою «суб' єкт дії», засвідчений у давніх лексикографічних працях і неофіційно поширений у відповідній виробничій сфері, спричинився до розвитку вторинного, предметного значення - інструмента (знаряддя) дії. Таке явище поширене у мові. I більше того, іноді обидва значення («суб’єкт» та «інструмент») функціонують паралельно (пор.: бомбардувальник 1. ‘бомбардувальний літак'; 2. ‘льотчик такого літака' - ОлЕКСенко 2005: 81). Іноді ж відбувається «звуження семантики словотвірного типу до позначення лише назв предметів з тенденцією до спеціалізації суфіксів» (РЯСО 1968: 72), - що і відбулося зі значенням слова кайлувальник, напр.: «Розроблено методику розрахунку основних конструктивних параметрів наконечників розпушників-кайлувальників» (ПристАйло 2014: 2).

Інші словотвірні значення субстантивної зони, зокрема «приміщення для виконання названої вершинним дієсловом дії», пор.: пресувальня, помпувальня (ГІнзьург 2008: 54) (словотворчий формант -льн-[-я]), «предмет, за допомогою якого виконують дію», пор.: буксирувальник, гальмувальник (словотворчий формант -льник), вальцівка (словотворчий формант -івк-[-а]), гальмівник (словотворчий формант -івник), фрезарка (словотворчий формант -арк-[-а]), «предмет (об’єкт) як наслідок виконаної дії», пор.: вальиівка (словотворчий формант -івк-[-а]), штамповка (словотворчий формант -овк-[-а]), «речовина», пор.: фiльтрат (словотворчий формант -am), представлено поодиноко і спорадично, що не дає підстав для висновку про системність їхнього вираження.

Ад’єктивну зону відсубстантивних дієслів аналізованої лексико-семантичної групи репрезентовано семантичними позиціями «призначений для виконання названої твірним словом дії» $\mathrm{i}$ «пов'язаний з виконуваною названим твірним словом дією». Для вираження обох словотвірних значень використовують суфікс -льн-. Частина аналізованих вершинних дієслів здатна реалізовувати їх, пор.: буксирувальний, вальцювальний, каландрувальний, нівелювальний, помпувальний, пресувальний, фільтрувальний, фрезерувальний, фрезувальний, циклювальний, шабрувальний, шнурувальний, шприцювальний, штампувальний і под. Кількість словотвірних парадигм, у яких експліковано ці два значення, згідно з даними різних джерел, $\epsilon$ неоднаковою. Зокрема на основі свідчень лексикографічних праць, таку спроможність виявляють лише кілька вершинних дієслів, серед яких буксирувати, фрезерувати, шнурувати, итампувати, пор.: «Гідравлічні штампувальні преси за своїм устроєм принципово не відрізняються від кувальних ${ }^{4} \mathrm{i}$ «У віці біля сорока років,

\footnotetext{
${ }^{4} \mathrm{http}: / /$ techtrend.com.ua/index.php?newsid=20281
} 
коли Віталій Кіндратович засвоїв основні цінності та правили гри..., йому довірили керувати тим самим штампувальним цехом» (ГАвдьо 2006: 38). За рештою ж вербативів значиться один лексико-семантичний варіант. Наприклад, лише значення «призначений для виконання названої твірним словом дії» виражають деривати пресувальний, фільтрувальний, шприцювальний; семантику «пов' язаний з виконуваною названим твірним словом дією»-ад'єктиви вальцювальний, зондувальний, нівелювальний, фрезувальний, циклювальний, шабрувальний. Проте здатність вершинних дієслів передавати і інше значення ад'єктивної зони засвідчено у мовленні прикладами поєднання того чи того прикметника з відповідним іменником, пор.: «Ковальсько-пресувальний цех машинобудівного заводу складається з п'яти прогонів, у кожному 3 яких виконується певна технологічна операція»; ${ }^{5}$ «Могутній зондувальний підсилювач уперше зареєстрував і електромагнітне поле, що виникає при битті серця, і частоту цього биття». ${ }^{6}$

I нарешті, вербативи каландрувати, помпувати, за даними словників, взагалі не продукують похідних прикметників. Натомість достатньо поширене функціонування останніх - до того ж з двома значеннями - дозволяє не погодитись 3 тим, пор.: «Фактично в помпувальні встановлено не окремі помпи, а помпувальні (словотвірне значення „призначений для виконання названої твірним словом дії“) агрегати, кожен з яких складається зі з'єднаних між собою помпи та урохомника» (ГІнзьург 2008: 55) і «Поршень запускають в трубу на помпувальній (словотвірне значення „пов'язаний з виконуваною названим твірним словом дією“) станції і він проходить по трубі до іншої станції, реєструючи різного типу пошкодження.

Крім того, в ад'єктивній зоні словотвірних парадигм деяких дієслів трапляються й такі деривати, що експлікують одне зі значень. Наприклад, семантику «призначений для виконання названої твірним словом дії» передають девербативи: 1) зафіксовані (у словниках): боронувальний, кардувальний, клеймувальний, шустувальний, напр.: «Встановлення клеймувальної машини вивільнило велику групу робітників»; ${ }^{8}$ 2) незафіксовані: дискувальний, зенкерувальний, кермувальний, компостувальний, коткувальний, таврувальний, шлейфувальний, напр.: «Лущильник складається з рами, причіпного пристрою, робочих органів (дисків), механізму регулювання кута атаки дисків від $15^{\circ}$ до $30^{\circ}$, коткувального котка, ходової частини, пристрою для вирівнювання лущильника». ${ }^{9}$ Семантику «пов'язаний з виконуваною названим твірним словом дією» виражають незареєстровані у словниках похідні гальмувальний, мінувальний, сапувальний, напр.: «...безпосереднім виконавцем мінувальних робіт у самому місті був командир 11-го взводу спецпризначення лейтенант Михайло Татарський» (КАБАНЕЦь 2008).

\footnotetext{
${ }^{5} \mathrm{http}: / /$ bibliofond.ru/view.aspx $? \mathrm{id}=667814$

${ }^{6} \mathrm{http}: / /$ www.ukrreferat.com/index.php?referat=45788\&pg=1

${ }^{7} \mathrm{ntsh}$.org/content/gazotransportna-galuz-vazhliviy-element-energetichnoyi-bezpeki-ukrayini

${ }^{8} \mathrm{http}: / /$ language.br.com.ua/клеймувальний

${ }^{9} \mathrm{http}: / /$ www.propozitsiya.com/?page $=146 \&$ itemid $=3387$
} 
Незасвідченість такої кількості слів чи одного зі значень, очевидно, можна пояснити певним відставанням лексикографічної фіксації постійного оновлення і безперервних змін словникового складу мови. Ці зміни зумовлені кількома чинниками. По-перше, відбувається витіснення форм слів (зокрема дієприкметників активного стану), які за часів «злиття мов» були рекомендовані як бажані (ФТБ 1935: 6), а насправді не відповідають нормам української літературної мови, пор.: фільтрувальний (замість фільтруючий). По-друге, поширюється тенденція до заміни конструкцій із семантико-синтаксичним відношенням мети одиницею, у якій те ж значення виражається синтетично - за допомогою суфікса -льн-, пор.: пристрій для буксирування $\rightarrow$ буксирувальний пристрій, агрегат для помпування - помпувальний агрегат. По-третє, сполучуваність прикметника на -льн-[-ий] з іменником у деяких випадках засвідчує розширення меж семантичного обсягу у напрямку до виокремлення лексико-семантичного варіанту, не зареєстрованого раніше.

В ад'єктивній зоні словотвірних парадигм дієслів вальцювати, гальмувати та фільтрувати, крім дериватів на -льн-[-ий], виявлено ще похідні, утворені за допомогою суфікса -івн-, пор.: вальцівний, гальмівний, фільтрівний. Віддієслівні прикметники на -iвн-[-ий] традиційно передають семантику «здатний виконувати названу твірною основою дію». Упродовж кількох етапів розвитку, яких зазнала українська термінна наука, ставлення до цього словотворчого засобу і відповідних новоутворень було різним. Згідно $з$ настановами репресивних бюлетенів періоду «злиття мов», прикметники з власне українським суфіксом -івн-беззаперечно були вилучені зі словникового складу (Хроніка 1934: 141), бо «штучно віддаляли українську наукову термінологію від наукової термінології російської мови» (Хроніка 1934: 139). «Вижили» лише кілька з них, зокрема: рятівний, панівний, руйнівний, гальмівний, будівний, чарівний, фільтрівний, засівний, гартівний, нищівний (КочЕРГА 2010: 25). Необхідність виправити ситуацію сьогодні видається як ніколи нагальною. Одначе процес цей тривалий і через надмірну обережність у вживанні властивих українській мові термінів, підсвідому меншовартісність, побоювання утворити одиницю, яка не має точних відповідників в інших мовах (КочЕРГА 2000: 19), супроводжується іноді певними труднощами, пов'язаними з розмежуванням словотвірних значень і використовуванням типових для цього словотворчих засобів, що спричинює відповідно нерозрізнення понять, а іноді і їхнє дублювання. Наприклад, характерну семантику «здатний виконувати названу твірною основою дію» виражає лише прикметник фільтрівний. Але, крім неї, цей ад'єктив дублює ще два словотвірні значення, експліковані дериватом фільтрувальний, утвореним за допомогою суфікса -льн- (ВТС 2009: 1537). А отже, спеціалізація суфікса на вираженні тієї чи тієї семантики порушується. Натомість значення прикметників вальиівний і гальмівний взагалі не має стосунку до того, що традиційно мав би виражати суфікс -івн-. Унаслідок цього відбувається дублювання не властивих для того чи того словотворчого засобу значень. Тому про системність вираження типового словотвірного значення за допомогою суфікса -iвн- говорити поки що не доводиться. 
У словотвірних парадигмах дієслів букерувати, гільйотинувати, грейдерувати, кернувати, тампонувати, трісрувати, флейцювати, чизелювати, шлюзувати, шомполувати дериватів-прикметників не виявлено. Наповнення вербальної зони словотвірних парадигм відсубстантивних дієслів зі словотвірним значенням «діяти інструментом, названим твірною основою», які сформовані за допомогою суфікса -yвa-/-юва-, детерміноване значною мірою належністю відсубстантивного дієслова до групи загальновживаних слів чи термінів, а серед останніх - вузькоспеціальних чи загальновідомих.

Вербальна зона загальновживаних дієслів, до яких належать бинтувати, боронувати, гальмувати, кайлувати, мінувати, решетувати, є обмеженою. Ïї складають деякі різновиди темпоральних та квантитативних модифікацій. Темпоральність представлено дієсловами на позначення завершального (фінітивного) етапу дії. Засобом вираження його слугують префікси за-, no-, npu-, роз-. Більшість 3 наведених слів здатні реалізувати фінітивне значення за допомогою двох і більше словотворчих засобів, що свідчить про відповідну глибину семантичних позицій у межах однієї словотвірної парадигми, пор.: боронувати - заборонувати, поборонувати, розборонувати; бинтувати забинтувати, прибинтувати, розбинтувати; инурувати - зашнурувати, розшнурувати тощо. До того ж значення девербативів або збігається, утворюючи дублети, або, попри спільне загальне темпоральне значення, відрізняється семантичними відтінками. Наприклад, перфективи заборонувати, поборонувати, розборонувати в основному вияві позначають «завершити виконання дії з використанням борони», а отже, виступають дублетами, напр.: «Поралив [Іван Михайлович], поборонував, засіяв добру латку просом» (ОлЕФІРЕнко 1994: 36); «Після внесення комплексних мінеральних сумішей землю треба ще раз перерити й розборонувати»; ${ }^{10}$ «Данько, заборонувавши перед посівом ріллю, почав тепер волочити ниву вдруге, зароблюючи в землю посіяне зерно» (ЦюПА 1958: 34). Рідше дериват заборонувати може дещо конкретизувати попередню семантику, вказуючи на дію, пов'язану з розпушенням бороною зораної землі після сівби, напр.: «Орендар мусив зорати землю, засіяти та заборонувати іiі, а вирощений врожай зібрати і обумовлену його частину перевезти до току господаря» (СироткІн 1994: 158).

У словотвірних парадигмах інших вершинних дієслів перфективи, утворені за допомогою різних словотворчих засобів, відрізняються певним семантичним відтінком, зумовленим напрямком, результатом, способом виконання дії. Наприклад, префікси за- і роз-, поєднуючись з основою дієслів, мотивованих іменниками на позначення засобу дії, продукують похідні з протилежною семантикою, пор.: забинтувати - розбинтувати, замінувати розмінувати, зашнурувати - розшнурувати, напр.: «Першою отямилася Віра... Забинтувала закривавлену ногу, дала укол» (Мотрич 2001: 188) і «Вона [Мирослава] спиртом із слоїка помила руки і зразу ж підступила до нього, відкотила розрізаний рукав гімнастьорки і розбинтувала руку...» (Головко

${ }^{10} \mathrm{http} / / /$ kamnu.net/index.php/dopomogaporad/11171-viroshhuvannya-luka-batuna.html 
1986: 204); «- А приміряй... - кинула, позіхнувши мати й наказала, щоб Ганько допоміг узути й зашнурувати черевички» (ХАРчук 1986: 263) і «Сава насилу випростав руку з лямки рюкзака, розшнурував його» (БЕРдник 1988: 92).

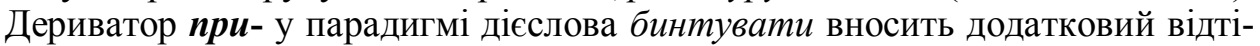
нок значення «забинтовуючи, прикріпляти до чого-небудь», пор.: прибинтувати, напр.: «- Йому [Порфирові] гарно, а мені... А то ще було шиферину прибинтував до руки і в школу не йде: «Я, мамо, поранений... Розбинтувала, а там нема нічого... Отакий фронтовик!» (ГончАР 1988: 297).

Квантитативні модифікації репрезентовано трьома різновидами значень. Перший з них формують дієслова, що виражають кратність вияву самої дії. Виразником багатократності є префікс пере-, який вказує на повторне виконання дії, пор.: переборонувати, переклеймувати, перемінувати, перетаврувати, перешнурувати, перебинтувати, напр.: «Він [Гурський] наказав перебинтувати рану і відвезти полоненого у Рогізне до лікаря, щоб той дістав із плеча кулю» (ЦимБАлюк 2009: 60).

До другого різновиду належать дієслова зі значенням інтенсивності виконуваної дії. 3 трьох традиційно виокремлюваних модифікацій (ВиховАнецьГороденськА 2004: 238-239) у словотвірних парадигмах аналізованих дієслів виявляємо деривати із семантикою достатньої інтенсивності. Засобом вираження iї слугують форманти про-, ви-, $\boldsymbol{y}$-, пор.: проборонувати, викайлувати, укайлувати, вирешетувати, прошнурувати, ушнурувати, напр.: «Зорану землю неодмінно треба було добре проборонувати, щоб дощова вода затрималась на рівно обробленій ділянці» (СУМ 8: 123).

Третя підгрупа квантитативних модифікацій визначає спрямованість дії на велику кількість об' єктів. Розподільні, або так звані дистрибутивні, дієслова постають за допомогою словотворчих засобів пере-, no-, пор.: переборонувати, переклеймувати, перетаврувати, покайлувати, поклеймувати, потаврувати, перешнурувати, напр.: «Собакаря ж та Полового у Катеринодарі перед військом було катовано батогами, а далі їх потаврували, обірвали їм ніздрі і заслали на кріпосні роботи у Сибір» (КАщЕнко 1992: 252).

Вербальну зону відсубстантивних дієслів - загальновідомих термінів, серед яких вальиювати, зондувати, компостувати, помпувати, пресувати, фільтрувати, фрезерувати, фрезувати, итампувати, представлено регулярними дериватами 3 темпоральним модифікаційним значенням «завершити виконання дії». Його реалізація відбувається за допомогою префіксів ви-, від-, за-, з-/зі-/с-, по-, про-, роз-, пор.: вифрезувати, відпресувати, відфільтрувати, відфрезерувати, відфрезувати, відштампувати, завальияювати, запомпувати, опресувати, пофрезувати, проштампувати, розвальиювати, спресувати тощо, напр.: «Ложка була такою важкою, наче її не відштампували, а відлили з благородного металу» (М. Федорченко); ${ }^{11}$ «Коли на місце події приїхали військові інженери і запомпували у свердловину 12 тонн води, вона вся кудись зникла». ${ }^{12}$ Іноді у ролі виразника експлікованого значення

\footnotetext{
${ }^{11} \mathrm{http}: / /$ otrok-ua.ru/ua/authors/info/fedorchenko-2.html

${ }^{12} \mathrm{http} / / /$ www.svoboda-news.com/arxiv/pdf/1997/Svoboda-1997-022.pdf
} 
використовують два і більше словотворчих засоби. В одному випадку вони утворюють дублети (напр., спресувати - опресувати), а в іншому - виражають додаткові семантичні відтінки. Наприклад, антонімні префікси за- - poз-, поєднуючись з основою дієслова вальц̧ювати, формують деривати, що передають завершальний етап протилежних за значенням дій, пор.: завальцюва$m u$ - розвальизювати, напр.: «Щоб відремонтувати вакуумний коректор (посипалась мембрана), я розвальц̧ював його, вирізав мембрану з гумової лодки, посадив іiі на герметик і завальц̧ював знову». ${ }^{13}$ Девербатив обвальц̧ювати виражає ту ж семантику, що і дієслово завальц̧ювати, з певною конкретизацією місця поширення дії - іï виконують з усіх боків (довкола) об’єкта.

Певної спеціалізації, детермінованої сферою використання, набувають префікси від- і про- у словотвірній парадигмі дієслова штампувати. Цей вербатив утворено від іменника штамn зі значеннями: 1. 'форма з металу або якого-небудь іншого матеріалу для серійного виготовлення деталей чи якихось інших дрібних предметів шляхом штампування'; 2. 'вид печатки прямокутної форми з гуми з опуклим зображенням тексту назви певної установи, організації і т. ін.' (ВТС 2009: 1631). Завершальний етап виконання дії, номінованої дієсловом штампувати, що мотивоване іменником у першому значенні, експлікує префікс від-, напр.: «За місяць (176 годин) робітник відштампував 1200 деталей», відповідно другий лексико-семантичний варіант реалізується девербативом проштампувати, утвореним за допомогою префікса nро-, напр.: «Йому [Григорію Коляді] потрібно виготовити печатку, якою він міг би проштампувати книги, що передає Музею». ${ }^{14}$

Наповнення вербальної зони дієслів - вузькоспеціальних термінів, серед яких дискувати, коткувати, нівелювати, шабрувати, шлейфувати, шпунтувати, є мінімальним і представленим лише похідними одиницями 3 дериваційним значенням «завершити виконання дії». Засобом вираження його слугують префікси за-, з-/c-, по-, при-, пор.: задискувати, закоткувати, знівелювати, покоткувати, прикоткувати, пришабрувати, зашлейфувати, зашпунтувати.

3 огляду на тісний зв' язок темпорального фінітивного значення з результативним спостерігається деяке маскування ступеня десемантизації префікса, унаслідок чого не завжди можна однозначно установити семантичну різницю між префіксальним та безпрефіксним дієсловами і відповідно беззаперечно визначити статус перфектива - дериват $з$ модифікаційним значенням (задискувати, знівелювати, запомпувати, зашлейфувати, зашпунтувати) чи корелят доконаного виду (закомпостувати, зашлюзувати, позондувати, прозондувати, прокомпостувати, скатапультувати). Перший 3 них формує дериваційний потенціал вершинного дієслова, інший - перебуває поза площиною словотвірної парадигми.

У словотвірних парадигмах дієслів зенкерувати, кардувати, каландрувати, шприцюювати, иустувати девербативів вербальної зони не виявлено.

\footnotetext{
${ }^{13} \mathrm{http}: / /$ www.energo.com.pl/ua/технологія/технологія_3.html

${ }^{14} \mathrm{http}$ ://igordudnik.livejournal.com/395092.html
} 
Отже, дериваційна спроможність відсубстантивних дієслів зі значенням «діяти інструментом, названим твірною основою», утворених за допомогою суфікса -yва-/-юва-, зумовлена належністю вершинних дієслів до загальновживаної лексики чи термінів, а серед останніх - до автохтонних чи запозичених. Словотвірні парадигми більшості вербативів є тризонними з характерними семантичними позиціями: у субстантивній зоні - «опредметнена дія», «суб'єкт дії»; в ад'єктивній - «призначений для виконання названої твірним словом дії», «пов'язаний з виконуваною названим твірним словом дією»; у вербальній: для більшості дієслів - «завершення виконання дії» (темпоральні модифікаціi); для загальновживаних, крім того, - «багатократний вияв дії», «достатньої інтенсивності вияв дії» $\mathrm{i}$ «дистрибутивність виконуваної дії» (квантитативні модифікаціi).

Дериваційні парадигми вузькоспеціальних термінів, зокрема іншомовного походження, є двозонними з окресленими семантичними позиціями субстантивної й ад'єктивної зон (зенкерувати, кардувати, каландрувати, шприщювати, шустувати) або однозонними з транспозиційним значенням «опредметнена дія» субстантивної зони (букерувати, гільйотинувати, грейдерувати, кернувати, тампонувати, трієрувати, флейцювати, чизелювати, илюзувати, шомполувати).

Віднесеність похідного до тієї чи тієї словотвірної зони визначає його спосіб творення. Деривати субстантивної й ад'єктивної зон постають унаслідок суфіксації, вербальної - префіксації.

Загалом дериваційна спроможність відсубстантивних дієслів зі значенням «діяти інструментом, названим твірною основою» 3 огляду на їхню семантичну різноплановість (заповнення трьох словотвірних зон), потенційну здатність до терміноутворення $є$ певною мірою системною, передбачуваною, але обмеженою у вираженні семантичних позицій.

\section{Джерела}

БЕРДник 1988 = БЕРдник О. П. Вогнесміх. Роман-феєрія. Київ, 1988.

Бєляков $2011=$ Бєляков В. Ф. Шляхи зменшення часу отримання метеорологічної інформації при організації стрільби і управління вогнем наземної артилерії. Військово-технічний збірник 2011/1: 144-148.

БІчуя 1982 = БІчуя Н. Л. Квітень у човні. Повісті, оповідання. Київ, 1982.

БоБРишев 2014 = БоБРишЕВ О. Ю. Технологія оперативного відновлення профілей температури і вологості за даними супутникових вимірювань. Геополитика и экогеодинамика регионов. Т. 10. Вып. 1. Симферополь, 2014. 382-385.

Войтюк 2008 = ВойтюК Д. Г. та ін. Сільськогосподарські машини. Основи теорії та розрахунку. Суми, 2008.

ВольвАч $2010=$ Вольвач П. Кляса. Роман. Харків, 2010.

ГАВдьо $2006=$ ГАвдьо І. Р. Фіктивний шлюб. Повість. Львів, 2006.

Головко 1986 = Головко А. В. Твори. Т. 2. Артем Гармаи. Роман. Київ, 1986.

ГончАР $1988=$ ГончАР О. Твори. Т. 5. Тронка. Роман у новелах. Бригантина. Повість. Київ, 1988. 
ГОНЧАР 2001 = ГОНЧАР О. Т. Вибрані твори. Т. 2. Людина світу, син Дніпра. Роман. Дніпропетровськ, 2001.

ДРеВАЛЬ 2005 = ДРеВАЛЬ М. Б. Розвиток методів зондування плазми пучком важких іонів і його реалізація на стелараторі ТЈ-II. АКД. Харків, 2005.

ЖДАнОВА $2006=$ ЖдАнОВА І. В. Удосконалення визначення показників механічних властивостей неоднорідних грунтових масивів за результатами статичного зондування. АКД. Київ, 2006.

ЗАГРЕБЕЛЬНИЙ 1961 = ЗАГРЕБЕЛЬНИЙ П. А. Спека. Роман. Київ, 1961.

ЗБОЖНА 2002 = ЗБОЖНА О. М. ОСнови технологї̈. Тернопіль, 2002.

КАБАНЕЦь 2008 = КАБАНЕЦь С. Лавра: за лаштунками трагедії. Україна молода. №206 за 01.11.2008. [Електронний ресурс.] http://www.umoloda.kiev.ua/number/1280/196/ 45274.

КАЩЕНКО 1992 = КАЩЕНКО А. Ф. Оповідання про славне Військо Запорозьке низове. Київ, 1992.

КЛАВДІєВА 2000 = КЛАВДІєВА О. Ю. Міжтравне жовчовиділення, базальне та стимульоване дуоденальне зондування у здорових та хворих на хронічний некалькульозний холецистит з дискінезіями жовчного міхура. АКД. Запоріжжя, 2000.

Мотрич 2001 = Мотрич К. В. Ніч після сходу сонця. Роман. Київ, 2001.

НЕчУй-ЛЕВицький 1967 = НЕчУй-ЛЕВИЦький І. С. Неоднаковими стежками. Зібрання творів у 10 томах. Т. 8. Київ, 1967. 264-482.

ОЛЕФІРЕНКО 1994 = ОЛЕФІРЕНКО М. Хуторяни. Роман. Вітчизна 1994/11-12: 16-128.

ПристАЙЛо 2014 = ПРистАЙЛо М. О. Обгрунтування раціональних параметрів розпушника-кайлувальника з пружно-деформованим виконавчим елементом. АКД. Київ, 2014.

СиРОткін 1994 = СиРОткін В. Б. Традиції земельної оренди та особистого найму. В кн.: Пономарьов А. П., АртЮх Л. Ф., Косміна Т. В. та ін. Украӥнська минувшина. Ілюстрований етнографічний довідник. Київ, 1994. 157-160.

СиРотюк 1984 = СиРотюк М. Й. Твори. Т. 2. На крутозламі. Роман. Київ, 1984.

Тесленко 1989 = Тесленко О. Рапана старого Петера. В кн.: Сучасна фантастична повість. Київ, 1989. 265-302.

ТКАч 1988 = ТКАч Д. В. Крута хвиля. Романи. Київ, 1988.

ХАРчУК 1986 = ХАРчУК Б. М. Подорож до зубра. Повісті. Київ, 1986.

ЦимБАЛЮК 2009 = ЦимБАЛЮК Є. Обірвана молитва за Україну. Історичне есе. Рівне, 2009.

ЦюПА 1958 = ЦюПА І. А. Три явори. Оповідання. Київ, 1958.

ЧумАК 2000 = ЧумАК М. Г. Матеріали та технологія машинобудування. Київ, 2000.

ШАульський 2012 = ШАульсьКий Д. В. Конспект лекиій з дисиипліни «Основи геодезї̈». Харків, 2012.

\section{Література}

АцАРКИНА 1997 = АцАРКИНА Т. А. Семантика глагола и его словообразовательные возможности (на материале глаголов движения в польском языке в сопоставлении с чешским и русским). В кн.: Сятковский С., ТихомиРовА Т. (ред.) Проблемы изучения отношений эквивалентности в славянских языках. Москва, 1997. 215221.

БЕЗПОЯСКО-ГОРОДЕНСЬКА 1987 = БЕЗПОяСКО О. К., ГОРОДЕНСЬКА К. Г. Морфеміка української мови. Київ, 1987. 
БЕЛЯЕВА 1974 = БЕЛЯЕВА Т. М. Словообразовательная потенция, валентность и активность глагольных основ в английском языке. АДД. Ленинград, 1974.

БІлодІд 1987 = БІлодІд І. К. та ін. (ред.) Російсько-український словник. Т. 1. Київ, 1987.

БРАЗАУСКЕНЕ 1991 = БРАЗАУСКЕНЕ Е. М. СЛОвообразоватеЛьный потенцุиал префиксальных глаголов. АКД. Москва, 1991.

ВАЛЮХ 2005 = ВАЛЮХ 3. О. Словотвірна парадигматика іменника в украӥнській мові. Київ-Полтава, 2005.

ВАСИЛЕНКО-ШЕЛУДЬКО 2008 = ВАСИЛЕНКО П., ШЕЛУДЬКО І. СЛовник гірничої термінології. Київ, 2008.

ВИХОВАНЕЦЬ-ГОРОДЕНСЬКА 2004 = ВИХОВАНЕЦЬ І. Р., ГОРОДЕНСЬКА К. Г. Теоретична морфологія української мови. Київ, 2004.

Возний 1981 = Возний Т. М. Словотвір дієслів в украӥнській мові у порівнянні з російською та білоруською. Львів, 1981.

ВТС 2009 = БУСеЛ В. Т. (ред.) Великий тлумачний словник української мови. КиївІрпінь, 2009.

ГЕОРГИЕВА 1963 = ГЕОРГИЕВА Е. Семантична характеристика на отглаголните съществителни на -не и на -ние в българския език. В кн.: Славистичен сборник. По случай V Международен конгрес на славистите в София. София, 1963. 225-233.

ГІнзБург 2008 = ГІнзБург М. Д. Газопровід чи газолін? Ринок інсталяиій 2008/10: 5455.

ГоловАщук 1969 = ГоловАщук С. І. (ред.) Російсько-украӥнський словник. Т. 1. Київ, 1969.

ГОРОДЕНСЬКА 1981 = ГОРОДЕНСЬКА К. Г. Структура відіменних дієслів. В кН.: ГОРОДЕНСьКА К. Г., КРАВЧЕНКО М. В. Словотвірна структура слова (відіменні деривати). Київ, 1981. 20-108.

ГРЕЩУк 2007 = ГРЕЩУк В. Теоретичні засади основоцентричної дериватології. В кн.: ГРЕЩУК В. В., БАчкУр Р. О. та ін. Нариси з основочентричної дериватології. ІваноФранківськ, 2007. 6-38.

ДжочКА 2003 = ДжочкА І. Ф. Дериваџійний потенціал дієслів конкретної фізичної дії з семантикою створення об' єкта. АКД. Івано-Франківськ, 2003.

ЗЕмСКАЯ 1978 = ЗЕмСКАЯ Е. А. О парадигматических отношениях в словообразовании. В кн.: Русский язык. Вопросы его истории и современного состояния. (Виноградовские чтения 1-8.) Москва, 1978. 63-77.

ЗЕмСКАЯ 1982 = ЗЕмСКАЯ Е. А. Структура именных и глагольных словообразовательных парадигм в русском языке. В кн.: Актуальныле проблемы русского словообразования. Ташкент, 1982. 14-17.

КАЛДИЕВА-ЗАХАРИЕВА 1977 = КАЛДИЕВА-ЗАХАРИЕВА С. Отвлечени съществителни от глаголни основи в съвременния български книжовен език. Докторска дисертация. София, 1977.

КАЛИНОВич 1948 = КАлиНОвич М. Я. (ред.) Русско-украинский словарь. Москва, 1948.

КОЧЕРГА 2000 = КОчЕРГА О. Висловлювальні можливості української мови (спроба аналізу лексикографічних джерел). Вісник Національного університету «Львівська політехніка». Серія «Проблеми української термінології». №402. Львів, 2000. 19-22.

КОЧЕРГА $2010=$ КОЧЕРГА О. Процесові прикметники в науковій мові. Biсник Національного університету «Львівська політехніка». Серія «Проблеми української термінологї̈». №676. Львів, 2010. 23-26. 
КУБАЙчУК 2004 = КУБАЙчУК В. Хронологія мовних подій в Україні. Зовнішня історія української мови. Київ, 2004.

Кушлик 2011 = Кушлик О. Параметри словотвірної парадигми гомональних дієслівономатопів в українській мові. В кн.: Проблеми гуманітарних наук. Збірник наукових праць Дрогобицького державного педагогічного університету імені Івана Франка. Вип. 28. Філологія. Дрогобич, 2011. 55-72.

Кушлик 2012a = Кушлик О. Вербальна зона словотвірної парадигми предметних дієслів-ономатопів. Мовознавчий вісник. Збірник наукових праџь МОНМС Украӥни Черкаський національний університет ім. Б. Хмельнищького. Вип. 14-15. Черкаси, 2012. 159-167.

Кушлик 2012b = Кушлик О. Дериваційний потенціал відприкметникових каузативних параметричних дієслів. Spheres of Culture. Vol. 1. Lublin, 2012. 176-185.

Кушлик 2012c = Кушлик О. Словотвірні параметри есивних дієслів зі значенням фізичного стану суб'єкта. В кн.: Науковий вісник Чернівецького національного університету імені Ю. Федьковича. Слов'янська філологія. Вип. 648-649. Чернівці, 2012. 288-291.

Кушлик 2012d = Кушлик О. Специфіка структури та семантики словотвірних парадигм відприкметникових інхоативних дієслів. Украйнська мова 2012/4: 56-67.

ЛУКАШАНЕЦ 1981 = ЛУКАШАНЕЦ А. А. Словообразовательные гнезда глаголов в русском и белорусском языках (на материале одной из групп глаголов конкретного физического действия). АКД. Москва, 1981.

МАМРАК 1982 = МАМРАК А. В. Продуктивність словотвірних типів у сучасній українській мові (на матеріалі утворень з -ник). Мовознавство 1982/4: 46-49.

МАНАчУРЯН 1981 = МАНАчУРЯН Р. С. Словообразовательные значения и формы в русском и армянском языках. Ереван, 1981.

МорозовА 1984 = МорозовА Т. С. Синтаксические свойства глагола и его словообразовательный потенциал. Проблемы структурной лингвистики. Москва, 1984. 81-95.

НЕЧАЕВА 1984 = НЕЧАЕВА В. Ф. Словообразовательные гнезда глаголов говорения в современном болгарском языке. АКД. Ленинград, 1984.

ОЛЕКСЕНКО 2005 = ОЛЕКСЕНКО В. П. Словотвірні категорії іменника. Херсон, 2005.

ПглЕцький 2004 = ПллЕцький В. Сучасний український термін (проблеми збереження національномовної самобутности). Вісник Національного університету «Львівська політехніка». Серія «Проблеми української термінологї». Вип. 34. Ч. 1. Львів, 2004. 428-437.

ПозНАНСьКИй 2014 = ПозНАНСьКий Р. В. Віддієслівні абстрактні іменники, мотивовані вербативами лексико-семантичного поля «аграрне виробництво (рослинництво)» в українській мові. Вісник Житомирського державного університету. Вип. 73. Житомир, 2014. 222-226.

ПосЛАВСьКА 2006 = ПосЛАВСьКА Н. М. Структура і семантика словотвірних парадигм дієслів із семою руйнування об'єкта. АКД. Івано-Франківськ, 2006.

ПузІк $2000=$ ПузІк А. А. Відприкметникові дієслова у німецькій, англійській та українській мовах. АКД. Донецьк, 2000.

РоднінА 1980 = РоднінА Л. О. Відображення словотвірної системи сучасної української мови у Словнику української мови. В кн.: Слово і фразеологізм у словнику. Київ, 1980. 76-81.

РЯСО 1968 = Русский язык и советское общество. Т. 2. Словообразование современного русского литературного языка. Москва, 1968. 
СЕГІн 2003 = СЕГІн Л. В. Структурно-семантична типологія словотвірних парадигм дієслів динамічної просторової локалізованості в українській та польській мовах. АКД. Донецьк, 2003.

СЕЛІГЕЙ 2007 = СЕЛІГЕй П. Питоме і чуже в термінології: гармонія чи конфлікт? Bicник Начіональної академії наук України 2007/9: 20-28.

СТАХОВСьКА 2002 = СТАХОВСьКА Н. Ф. Семантична та словотвірна структура агентивно-професійних найменувань металургійної термінолексики. АКД. Дніпропетровськ, 2002.

СТУПАК 2011 = СТУПАК І. В. Структурно-семантичні та функціональні характеристики похідних каузативних дієслів у німецькій і украӥнській мовах. Донецьк, 2011.

СУМ = Словник украӥнської мови. Т. 1-11. Київ, 1970-1980.

Тихонов 1982 = Тихонов С. А. Структура словообразовательных цепочек звучания. В кн.: Актуальные проблемы русского словообразования. Ташкент, 1982. 124-130.

УГ-1986 = РУСАНОВСКИЙ В. М., ЖОВТОБРЮХ М. А., ГОРОДЕНСКАЯ Е. Г., ГРИЩЕНКО А. А. (ред.) Украинская грамматика. Киев, 1986.

ФТБ 1935 = Фізичний термінологічний бюлетень. №4. Київ, 1935.

Хроніка 1934 = Хроніка НДІМ 1933-1934 рр. Мовознавство 1934/2: 139-145.

ЧИКАНЦЕВА 1984 = ЧИКАНЦЕВА Т. В. Словообразовательные парадигмы непроизводных глаголов современного русского языка. АКД. Ленинград, 1984.

Юрчук 1979 = Юрчук Л. А. Суфіксальний дієслівний словотвір. В кн.: Словотвір сучасної украӥнської літературної мови. Київ, 1979. 171-210.

ЯРОшЕнко 2004 = ЯРОшЕнкО Н. О. Зіставний аналіз словотвірних парадигм дієслів сажать, садити і sq̨dzić у російській, українській і польській мовах XIX-XX ст. Лінгвістичні студії. Вип. 12. Донецьк, 2004. 299-308.

ЯруллинА 1980 = ЯруллинА Т. С. Словообразовательные возможности русских непроизводных глаголов (к вопросу взаимодействия грамматики и словообразования). АКД. Москва, 1980.

BuZÁSSYOvÁ 1974 = BuZÁSSYOVÁ K. Sémantická štruktúra slovenských deverbatív. Bratislava, 1974.

GRZEGORCZYKOWA 1969 = GRZEGORCZYKOwA R. Czasowniki odimienne we współczesnym języku polskim. Warszawa, 1969.

JADACKA 2001 = JADACKA H. Słownik gniazd słowotwórczych współczesnego języka ogólnopolskiego. T. 2. Gniazda odrzeczownikowe. Kraków, 2001.

JADACKA 2004 = JADACKA H. Słownik gniazd słowotwórczych współczesnego języka ogólnopolskiego. T. 3. Gniazda odczasownikowe. Kraków, 2004.

KUSHLYK 2013 = KUSHLYK O. Derivation potential of motivated by adjectives verbs of mental state of the subject in the Ukrainian language. In: Management and Education. Vol. 4. Humanities and Social Sciences. Burgas, 2013. 71-78. 